\title{
Youth Engagement and the Colbert Nation: From Passive Consumer to Passively-Active Viewer
}

\begin{abstract}
The youth of today have been cast in a state of temporality, with no way of knowing whether their condition is permanent or transitionary. Today's youth are regarded as a low priority by politicians, and scholars and policymakers often view this disconnection as a crisis in citizenship within advanced industrial democracies. This disengagement from electoral politics has contributed to several underlying issues, such as, a feeling of alienation from the political process, and a growing disinterest toward the political system. However, young people are now engaging in nonelectoral forms of civic and political engagement, such as, participatory culture, which facilitates space for political and civic youth mobilization, and this, in turn, promotes democratic values of involvement.

This paper examines the institutionalization of political media satire, with a specific focus on the commodification of the content found on The Colbert Report. I will explore the role of institutionalized political satire within hegemonic institutions, and argue that $T C R$ creates a viewership based on the fetishism of commodities. However, where fetishism often generates passive reception, I argue that the commodification of political content and TCR fandom culture generates a passivelyactive viewer, and facilitates a space for youth engagement. For reasons discussed, it remains an open question whether young people will take full advantage of the political knowledge and awareness gained from watching $T C R$, and whether this will lead to future political advocacy.
\end{abstract}

KEYWORDS: Colbert Report, civic engagement, political media effects, political satire, political participation, youth participation.

The youth of today are living through a very difficult time, often "cast in a condition of liminal drift, with no way of knowing whether it is transitory or permanent" (Bauman 2004:76). This young demographic, who are often regarded as a 
low priority by politicians, are disengaging from electoral politics and are set adrift to face the harsh realities of high youth unemployment, cuts to youth services and education budgets and an increase in university tuition fees (Sloam 2014: 665). Young people's (under the age of 30) disconnection from electoral politics has often been viewed by scholars and policy makers as marking a crisis in citizenship within advanced industrial democracies (Stoker 2006). This disconnection has contributed to several underlying issues such as a feeling of alienation from the political process; a show of disinterest and incomprehension toward the political system (Sloam 2014) and a growing cynicism toward politicians (Stoker 2006). Moreover, this disillusionment with politics has been illustrated by several mass demonstrations in recent years, such as the 2011 Occupy Movement in the United States, or the 2012 mass student rallies in Quebec, Canada.

In the United States, in particular, youth voters (aged 18-29) have traditionally stood out for their consistently low levels of electoral participation (File 2013). For instance, according to a report on youth political participation published by The Center For Information and Research on Civic Learning and Engagement, "The turnout for young people (both under-30s and under-25s) has only been lower in three presidential elections - 1988, 1996, and 2000 - since the voting age was lowered to 18 in 1972" (CIRCLE 2014). Americans are now beginning to see a shift in the direction of youth engagement, from Obama's "Yes We Can" campaign, to an increase in civic education (Sloam 2014) and this strategy has helped to increase youth voter turnout (18-24) in 2004 and 2008. However, by the next election in 2012 , the youth share of votes cast fell, driven by the decline in voter turnout (CIRCLE 2014), displaying a rise in a disconnection between young Americans and electoral politics.

\section{Youth, New Media and Political Participation}

A recent study by the Institute of Politics at Harvard University found higher levels of volunteering among millennials (born between the early 1980s and 2000s), in comparison with the baby boomer generation (born between 1946 and 1964) (cited in: Zuckerman 2014). Young people are now engaging in non-electoral forms of civic and political engagement, from activities such as petitions, boycotts and demonstrations to consumer politics, community campaigns, or voicing their concerns through social media. Moreover, in a survey conducted by Kahne and Cohen (2012), they found strong evidence of a rise in youth participatory culture and that young people (under age 30 ) are using new media to engage in political discussion or to share civic material. Further, their research found that American youth who are involved in interest-driven online communities appear to be gaining political/ civic knowledge, skills and networks. New media has come to play a prominent role in the civic and political life of young people, as it has given them a political voice and influence by providing them with the tools for political and civic expression and this has opened up space for political/civic mobilization (Bennett 2008). 
Participatory culture, through mediated practices such as texting, blogging and social networking, has helped young people share their experiences and has encouraged the creation of meanings and action. For instance, Castells (2011) points out how Facebook and other social networking sites illustrate how young people increasingly construct their sense of community and identity online. Participatory culture has therefore provided young people with the opportunity to become directly involved in the public discourse. Instead of arguing about the decline of youth civic and political engagement, we should instead view their level of engagement as evolving rather than declining.

\section{Research Question}

In this paper, I will examine the institutionalization of political media satire, with a particular focus on the commodification of the content, found on The Colbert Report (hereinafter referred to as $T C R$ ) and explore the ways in which $T C R$ serves as a system for the perpetuation of corporate-owned culture and the accumulation of commodity consumption among audience members. Further, this paper will attempt to answer whether youth engagement with the Colbert Nation can be considered citizen engagement (civic or political participation), or is it simply reinforcing passive consumerism, acting solely as consumerist entertainment?

This paper analyzes the role of institutionalized political satire and argues that $T C R$ creates a viewership based on the fetishism of commodities. However, where fetishism often generates passive reception, this paper has found that the commodification of political content and fandom culture generates a passively-active viewer and facilitates a space for youth engagement. Furthermore, TCR fosters participatory culture through the culture industry, but nonetheless, for reasons discussed, it remains an open question whether young people will take full advantage of the political knowledge and awareness gained from watching $T C R$ and whether this will lead to future political advocacy.

\section{The Rise of Institutionalized Satire}

Following the postwar economic boom in the United States during the mid-20th century, television became a part of postwar American culture as it was thought to provide the solution for mending the broken homes and hearts of wartime life (Spigel 1989). Further, television gained more commercial and domestic acceptance and became the most sought-after appliance for sale in postwar America, as it was shown to restore family togetherness and renew faith in consumer capitalism (Spigel 1992:2-3). America's move to a postwar consumer society has been largely dictated by television-based advertising, which acted as a receiver of consumer culture that was directed into the living rooms of television owners.

Moreover, as more advertising agencies adopted this medium as a strategy "to create awareness, change attitudes, [and] influence behavior" (Moody 2012: 2). This 
allowed for the television to reign as the dominant home entertainment system in the United States for more than 60 years. For instance, since 1991, Comedy Central (CC) has embraced political satire as a brand market as they felt that it was "economically sufficient when focusing on a narrower demographics" and content for a smaller audience share (Gray et al. 2009: 14). By 1993, CC's institutionalized political satire garnered the network critical acclaim and wider cable system carriage and this has helped to strengthen their brand identity. Starting with the successful launch of Politically Incorrect in 1993, Comedy Central found homes for successful satirical hits such as The Daily Show (1996-1999); South Park (1997-present); The Daily Show with Jon Stewart (hereinafter referred to as TDS) (1999-present); Chappelle's Show (2003-2006) and The Colbert Report (2005-2014).

\section{Defining Political Satire}

Having a long history in political commentary, satire was adopted by the Ancient Greeks as a form of political criticism and mockery. It continued to flourish in stable societies, presupposed homogeneous moral standards, all the while seeking progress and the betterment of humanity (Colletta 2009: 304). However, as satire seeks to both educate and entertain the audience (Holbert et al. 2011: 191), we should be careful with classifying it as a single literary form since there are many varieties of satire that adopt different techniques to persuade and captivate the audience. Two of the most widely used styles in contemporary Western society are Juvenalian and Horatian, both of which have been named after Roman poets (Sander 1971). Horatian satire emphasizes the elements of play and laughter and seeks to mock the imperfections of society through light humour. On the other hand, Juvenalian satire is more abrasive, addressing social evils through scorn and ridicule. It is more direct, "full of rage and disgust at universal corruption," (Freedman 2008: 2) and laughs with contempt with humanity's “incongruities and base hypocrisies" (Sander 1971: 235). In other words, if we were to break satire down into the traditional dichotomy of tragedy versus comedy, Horatian satire would be defined as comedy and Juvenalian satire would be classified as tragedy (Sander 1971).

Western contemporary political satire is a very powerful artistic form that reveals political or social ills for a higher understanding of public life (Rahimi 2015: 270) and explores the gaps and contradictions of society (Knight 2004: 50-51). Moreover, it can also be viewed as an instrument of resistance that challenges hegemonic political ideologies and undermines, demythologizes and demystifies governmental narratives. For instance, in Jonathan Swift's 1729 satirical critique of English occupation in Ireland, $A$ Modest Proposal, he challenges the dominant political narrative regarding the causes of the Irish famine and uses satire to challenge the reader's conception of poverty and social injustice. That said, Swift uses satire as a technique to not only entertain the reader, but to also challenge the reader's political views (Cameron 2015: 277-279). 


\section{Literature Review: Political Satire and Contemporary Society}

In October 2005, TCR emerged as a spin-off from TDS and is hosted by the fictionalized persona of conservative pundit, Stephen Colbert, who was 'molded' after conservative media personality, Bill O'Reilly. What is unique about the show's comedic appeal is his over the top spin on news topics and use of deadpan satire to deliver his satirical comedy, his humorous critique of conservative media personalities, such as Rush Limbaugh, and his "explicit rejection of the need for facts in engaging in political debate and assessing political arguments" (Baumgartner and Morris 2008: 623). TCR has collected dedicated viewers, as well as critical acclaim through numerous awards, such as, two George F. Peabody Awards in Excellence in News and Entertainment (2008, 2012); five Primetime Emmy Awards (2008, 2010,2013) and a People's Choice Award for Favorite Late Night Talk Show Host (2014). By the end of 2013, TCR had become one of the most watched late-night talk shows among adults 18-49, the industry's key advertising demographic (Kissell 2014). Moreover, the show has attracted a prominently younger male audience (Morris 2009; Young and Tisinger 2006), who are more liberal (Young 2004) and who hold four or more years of postsecondary education (Morris 2009).

As political media satire has become more prevalent within the past decade, media scholars have been investigating how it might impact the political process in the United States. Recent studies have shown that late-night political satirical programs, such as $T D S$ and $T C R$, have the capacity to have a positive impact on society, especially among younger and more educated viewers. In a 2000 survey conducted by the Pew Research Center for the People and the Press, it was reported that 47 per cent of people under the age of 30 gained political knowledge and information about the presidential campaign through late-night comedy programming. Moreover, a 2008 Pew Research survey, found that 43 per cent of regular TCR viewers are younger than 30 years of age.

Hollander (2005) found evidence that young people are capable of gaining political knowledge through late-night comedy, but he states that their level of political competency and ability to express this political knowledge in a constructive manner remains an open question. Similarly, Young and Tisinger (2006) found that viewers of TDS are more politically knowledgeable and attentive in comparison to viewers of other late-night comedy shows, while Jones demonstrates a positive relation between fandom and citizenship and has stated that $T C R$ "invites the audience to play with politics, thereby offering not only pleasure and inclusion, but a degree of interpretive agency in constructing political meaning and understanding through such participation" (Jones 2009: 208). Other studies have found that TDS and TCR can increase youth's political knowledge and efficacy. For instance, McClennen suggests that TCR sparks an "active citizenry that combines activism and critical reflection with a healthy dose of fun" (2011: 166) and in Van Heertrum (2011), he suggests that $T D S$ and $T C R$ provide youth with a valuable resource for critiquing 
politicians and the media; this, he argues, can help shape and form their political identities. Furthermore, Xenos and Becker (2009) suggest that some of the most significant learning from $T D S$ may be related to the post-viewing behaviour, where viewers use this time to research for additional information.

However, Baumgartner and Morris's (2008) research found an increased affinity for the Republican Party and policies and argue that Colbert's attempts at poking fun of conservative personalities may be helping those same personalities spread their message. Further, their study found that Colbert's satirical humour and use of irony send out mixed messages to younger viewers and this may increase the chances that younger viewers may become less confident in their ability to understand politics (Baumgartner and Morris 2008: 634). Moreover, LaMarre et al. suggest that political ideology can play a factor in the effect Colbert's satire has on the viewer and concluded by stating, "The ambiguous deadpan satire offered by Stephen Colbert in 'The Colbert Report' is interpreted by audiences in a manner that best fits with their political beliefs" (LaMarre et al. 2009: 226).

Existing research on the effectiveness of political satire suggests that humour can work to attract initial public interest in serious issues, provoke critical questions and public discussion and promote a sense of hope that change is possible (Cameron 2015: 286). My current research analyzes the commodification of political content and fandom culture and argues that political media satire generates a passivelyactive audience and facilitates the emergence of a more democratically organized cultural domain. For instance, this paper has found that TCR has created the potential for citizen engagement and has also created a new model for activism, but it remains an open question whether young people will take full advantage of the political knowledge and awareness gained from watching $T C R$ and whether this will lead to future political advocacy.

\section{Participatory Culture}

The institutionalization of political satire and by extension the branding of TCR is an example of a media object that functions within monopoly capitalism. That is, the producers of TCR offer satisfying content to the audience in order to gain a loyal viewership and thus profit off of them through advertisement revenue and unpaid labour. Moreover, according to Jenkins, fans and consumers "are selective users of a vast media culture whose treasures, though corrupt, hold wealth that can be mixed and refined for alternative use" (Jenkins 2013: 27). Therefore, these media objects exemplify a move toward a participatory culture, one where audiences constantly shift between consumers and producers of content.

Participatory culture is characterized by "relatively low barriers to artistic expression and civic engagement, strong support for creating and sharing one's creations and some type of informal mentorship whereby experienced participants pass along knowledge to novices" (Jenkins 2009: xi). New media technologies provide 
young people with new possibilities for civic and political participation and offer unconventional avenues to influence the political realm. By facilitating access to and through the opening up of new spaces, young people can readily access political information and are provided with "tools and avenues for political expression and mobilization" (Bennett 2008). Participatory culture thus has the potential to empower young people, enhance participation in politics and provide both motives and opportunities for political engagement" (Kann et al.2007).

Media consumption and the normalisation of convergence culture has been shaped in a multi-dimensional framework, where viewers have now become producers of content (for example, fan-based videos on YouTube), while remaining as consumers of culture. And as journalist, Rachel Sklar (2006) remarked in the Huffington Post, "The people behind TCR may be the smartest minds in television: While everyone else frets about YouTube, Web TV and platform integration, Stephen Colbert \& Co. are already galvanizing the online to action and integrating usergenerated content into the show." The rise of the culture industry has played a very important role within the institutionalization of political satire. It has "built upon interactions among older and newer media logics—where logics are defined as technologies, genres, norms and behaviours and organizational forms-in the reflexively connected fields of media and politics" (Chadwick 2013: 4). TCR not only brings awareness to the follies within contemporary society, but the show commodifies political content for an increase in ratings and serves as a 'gateway' to a greater understanding of politics. TCR brand culture thus functions as a form of lifestyle politics for the viewer- "something one is, or does, rather than point to a particular consumer good one purchases" (Banet-Weiser 2009: 91). And so, TCR and the commodified political content shared with the viewers help shape their identity and consumes the very essence of their being.

\section{The Colbert Report and Fandom}

The Internet has helped to revive the concept of the public sphere, as it resembles a 19th century public house where patrons often frequent to discuss current events, or debate on general rules governing society. And according to media scholar, Sophia $\mathrm{McClennen,} \mathrm{by} \mathrm{targeting} \mathrm{his} \mathrm{program} \mathrm{at} \mathrm{youth} \mathrm{culture} \mathrm{and} \mathrm{by} \mathrm{'forcing'} \mathrm{his} \mathrm{audi-}$ ence to recognize their collective power, Colbert is reigniting this notion of the public sphere and how it can both be politically powerful and fun (McClennen 2011: 158). Youth-oriented political media satire offers one of the most powerful ways of reinvigorating the public sphere. It has helped to establish shared connections through online communities, foster a sense of solidarity and it has helped to mobilize a collective consciousness, regardless of geographical distance or location. Most importantly, members of the Colbert Nation function as an alternative social community, offering up symbolic solutions to real world problems and felt needs and an open space for imagined possibilities of change. 
In an interview with Neil Strauss for Rolling Stone, Colbert described the creation of the Colbert Nation: "We invented the Colbert Nation, but then we discovered it was real. We didn't make it happen, they self-organized it. I love that relationship. We can't always have it and you can't force that. You just have to acknowledge it. We're always planting seeds with the show and the challenge is, will we notice when a flower blooms and then pick that flower?" (Strauss 2009). Colbert has regularly opened up space for audience engagement, where he asks his audience "not only to applaud on cue but to take action in the real world" (Baym 2009: 150). His appeal to youth culture goes beyond the studio and into the homes of fans, where he invites the Colbert Nation to participate in the creation of the show by frequently calling on them to participate in various tasks such as, altering Wikipedia entries, or participating in various online contests.

Fan culture lies at the intersection of popular culture and participatory politics and fandoms, such as the Colbert Nation, are a defining characteristic of modernity. In their study on media activism and fan blogging, media scholars Catherine Burwell and Megan Boler found that "DIY fan culture provides significant insights into meaningful production and civic engagement within mediated worlds" (Burwell and Boler 2014: 115). Colbert's fandom is explicitly operated by Stephen Colbert and shared through coordinated media consumption and web-managed membership to form a safe space for political and civic participation. His creation of the Colbert Nation has given rise to a strong and dedicated fandom and this form of participation has helped youth create, critique and share work while expanding their social networks and offering new pathways into political/civic participation (Jenkins 2009).

In addition to his interactive segments, Colbert offers the Colbert Nation several avenues to interact with the show outside of the regular airtime. For instance, the Colbert Nation has an official website where fans can access past episodes, an official Facebook page, or you can follow both TCR and Colbert on Twitter. This merging of social networking with political satirical content has opened up space for introducing political discourse into the lives of young people. TCR's use of social media platforms gives the Colbert Nation the opportunity to interact with young people in a way that supports the development of a public sphere. And according to Burwell and Boler: "These kind of activities are not only generated by the program's producers but also initiated by fans themselves, who have started several thriving blogs dedicated to TCR, organized protests in support of striking writers and devoted countless threats to discussion of the show" (Burwell and Boler 2014: 117).

\section{The Culture Industry: The Commodification of Culture}

In "The Culture Industry: Enlightenment as Mass Deception," German social theorists, Theodor Adorno and Max Horkheimer, proposed that the normalization of consumerism has given rise to the creation of mass culture, or what can be considered manufactured culture. Further, they warn us of how the rise of the culture 
industry "turns all participants into listeners and authoritatively subjects them to broadcast programs which are all exactly the same" (Adorno and Horkheimer 1944: 121-122). With the support of mass media communications, the mediatisation of consumption has played a helping role in the propagation of commodity production through various forms of cultural commodities, such as radio, film and television. This propagation of commodity has distorted our perception of reality by deliberately fabricating our psychological needs and reinforcing our false consciousness. The culture industry, therefore, creates a need and then sells us something to fill this void and the product that is being sold is a set of complex desires that undermine the ability of individuals to be agents of their desires and emotions. Moreover, as American sociologist and cultural commentator, Todd Gitlin points out, "Time and attention are not one's own; the established social powers have the capacity to colonize consciousness and unconsciousness, as they see fit" (Gitlin 1978: 255).

The television can, therefore, be seen as a gateway for capital flow as it introduces viewers to a media environment that is interconnected with other forms of media. In the post network-era, Comedy Central has embraced political satire as a brand marker, as they felt that it was "economically sufficient when focusing on narrower demographics" and content for a smaller audience share (Gray et al. 2009: 14). Satirical comedy thus offers a specific brand of programming for the channel and audience and this provides a very distinct appeal that cannot be found elsewhere on television. Branding and "advertising in the media is a 'necessary elixir' of capital because with it media corporations gain and accumulate capital. It is necessary for the selling of media products, for the sale of services and consumer goods and for the ideological reproduction of capitalist relations"(Fuchs 2009). So while Comedy Central has adopted marketing strategies that aim to earn a loyal audience, they view fans of $T C R$ as commodities and future influencers of the cable network.

\section{Axes of Participatory Civics}

However, it would be dismissive to simply regard the Colbert Nation as merely 'passive' commodities within the culture industry. Is youth engagement with the Colbert Nation considered citizen engagement (civic or political participation), or is it simply reinforcing passive consumerism, acting solely as consumerist entertainment? In Nerw Media, Nerw Civics?, media scholar Ethan Zuckerman uses the term 'participatory civics' to refer to "forms of civic engagement that use digital media as a core component and embrace a post-'informed citizen' model of civic participation" (Zuckerman 2014: 156) and argues that practitioners of participatory civics have grown up on participatory media. Namely, practitioners have grown up in a digital culture where they can share their perspectives and views with the world, as well as see their influence regarding how many digital actors read, shared, or commented on these perspectives. 
Zuckerman has introduced a typology for thinking about different types of civic participation. Instead of critiquing online engagement as a form of slacktivism or clicktivism, which is a term Evgeny Morozov (2009) has used to describe "feelgood online activism that has zero political or social impact," Zuckerman's 'Axes of Participatory Civics' moves away from Morozov's 'zero sum game' by taking into consideration all levels of online and offline action as a form of participation, albeit with varying levels of impact. Moreover, as Clay Shirky argues, "To speak online is to publish and to publish online is to connect with others. With the arrival of globally accessible publishing, freedom of speech is now freedom of the press and freedom of the press is freedom of assembly" (Shirky 2008: 172).

Firstly, Zuckerman's horizontal axis refers to what is asked of you as a participant in a civic act. For instance, under thin engagement, your job is simply to show up, while, under thick engagement, your job is to figure out what needs to be done. Secondly, the vertical axis refers to what classifies as the 'levers of change,' for instance, the instrumental end refers to "engagement that has a specific, direct theory of change" (Zuckerman 2014: 159). And evaluating the success of any civic engagement requires asking what a civic actor hoped to achieve and whether he/ she achieved it. "Does thin engagement take advantage of strength in numbers? Does thick engagement take advantage of the creativity of those involved? Do instrumental approaches have a believable theory of change? Do voice approaches build engagement and grow movements?" (Zuckerman 2014: 163).

Media satire has attracted a younger viewing audience who see programs such as $T D S$ and $T C R$ as a more stimulating alternative from the more traditional forms of news broadcasting (Baumgartner and Morris 2011). Further, the programs have successfully integrated politically commodified content within the 'convergence' culture industry and this has created a nouveau genre of critical media literacy programming on television that has helped to educate viewers and inspire civic action. For instance, in January 2010, the Supreme Court ruled 5-4 in the case of Citizens United v. Federal Election Commission, which allowed for corporations to raise money through Super PACs (political action committees), for political campaigns without any legal limit on donation size. Shortly after the announcement, Colbert founded his own Super PAC, "Americans for a Better Tomorrow, Tomorrow," to raise awareness of the Citizens United Supreme Court decision, in order to bring awareness to how "American campaign finance lost all semblances of regulation and oversight" (McClennen and Maisel 2014: 38). With the help of the Colbert Nation, Colbert's Super PAC raised over $\$ 1.02$ million by January 2012 and the money helped draw attention to an issue, which had not received enough media attention, by the purchasing of advertisement space to run nationally televised mock Super PAC advertisements.

The institutionalization of political satire has revitalized the potential for civic engagement and has created a 'new model' for civic participation. When analyzing 
the activities instructed by Colbert through the lens of Zuckerman's Axes of Participatory Civics, we can argue that the actions of the Colbert Nation would fall under 'thin engagement' on the horizontal axis, since the actions taken up by the Colbert Nation have been solely organized by Stephen Colbert and TCR, with the exception of fan blogs and fan websites. Colbert's authority over the Colbert Nation, by either asking them to participate in a contest, or asking for donations, is contained within the limits of Colbert's directed instructions and would, therefore, be considered a voice approach, found on the vertical axis. In short, the actions of the Colbert Nation are very low-level in terms of change and are solely controlled through the instructions of Stephen Colbert. However, Colbert's adoption of participatory culture has the potential to enhance youth participation in politics by providing both motives and opportunities for political engagement. It not only promotes key democratic values of involvement and openness, but it also teaches youth about political mobilization (Kann et al. 2007).

\section{Conclusion}

Participatory culture has the potential to enhance youth civic and political participation. Not only does it promote democratic values of involvement, but it also facilitates political mobilization. The institutionalization of political satire not only provides boundless entertainment for the viewer through a mixture of comedy and satire, but it also brings awareness to the follies within contemporary society (Young 2011). One of the main indicators of the success of TCR has been Comedy Central's demand for higher ratings and advertisement revenue. However, the commodification of political satire has created a new model of activism for fans, since the media objects generated from TCR contain political content that has the potential to mobilize the Colbert Nation. The "Colbert bump" for example, which is a term coined by Colbert to refer to the boost in popularity that guests, such as political candidates or celebrities, achieve by appearing on the show. Moreover, this boost in popularity exemplifies evidence of the Colbert Nation actively participating within the culture industry, which in turn has influenced real world events. For instance, Fowler (2008) found that Democratic congressional candidates who appeared on the program "went on to significantly out-fundraise their peers who were similarly matched in terms of political party, incumbency and prior donations but who had not appeared on the show" (cited in: Feldman et al. 2011: 25-26). And in 2009, Sports Illustrated noted that after Colbert had extended the "Colbert bump" to the U.S. speed skating team following the news of the team's sponsor announcing bankruptcy, the Colbert Nation was signed on as the official team's sponsor and raised nearly $\$ 200,000$ within the first week of Colbert's announcement (Feldman et al. 2011: 26).

In this paper, I have examined the institutionalization of political media satire and have argued that TCR creates a viewership based on the fetishism of commodities. However, where fetishism often generates passive reception, this analytical literature 
review has found that the commodification of political content and fandom culture generates a passively-active viewer and facilitates the emergence of a more democratically organized cultural domain. The "Colbert Report" has created the potential for citizen engagement and has also created a new model for activism, but nonetheless, for reasons discussed, it remains an open question whether young people will take full advantage of the political knowledge and awareness gained from watching TCR and whether this will lead to future political advocacy. This paper raises a number of questions that need to be addressed through future research. For one, we do not yet know whether engagement with the Colbert Nation has any impact on traditional modes of political engagement among youth. Moreover, it is hard to tell from this research whether or not members of the Colbert Nation were already politically engaged prior to joining the club, or if $T C R$ serves as an alternative entry point for youth participation into electoral politics.

To paraphrase Pierre Bourdieu (1998), it is not enough to say that what gets on television is determined by the owners, or the companies that pay for advertisement space, or by the government that gives the subsidies. However, it is important to keep these things in mind. It is important to know that Comedy Central is owned by Viacom (who also owns CBS) and that Stephen Colbert is to succeed David Letterman as the host of the Late Show on CBS in 2015. So with Colbert leaving behind TCR to compete for the late-night timeslot on CBS, what does the future have in store for the Colbert Nation?

\section{References}

Adorno, Theodor and Max Horkheimer. 1944. The Culture Industry: Enlightenment as Mass Deception. In Dialectic of Enlightenment, 94-136.

Banet-Weiser, Sarah. 2009. Home Is Where the Brand Is: Children's Television in a PostNetwork Era. In Beyond Prime Time: Television Programming in the Post-Network Era, 75-93. Routledge.

Baumgartner, Jody and Johnathan S. Morris. 2008. One "Nation," Under Stephen? The Effects of the Colbert Report on American Youth. Journal of Broadcasting E Electronic Media, 52(4): 622-643.

- 2011. Stoned Slackers or Super Citizens? The Daily Show Viewing and Political Engagement of Young Adults. In The Stewart/Colbert Effect: Essays on the Real Impacts of Fake News. McFarland.

Bauman, Zygmunt. 2004. Wasted lives: Modernity and Its Outcasts. Cambridge: Polity Press.

Baym, Geoffrey. 2009. Networked News: Stewart, Colbert and the New Public Sphere. In ICA Conference.

Bennett, W. Lance. 2008. Changing Citizenship in the Digital Age. Civic Life Online: Learning How Digital Media Can Engage Youth 1:1-24.

Bourdieu, Pierre. 1998. On Television. New York: New Press. 
Burwell, Catherine and Megan Boler. 2014. Rethinking Media Activism through Fan Blogging: How Stewart and Colbert Fans Make a Difference. In DIY Citizenship: Critical Making and Social Media. MIT Press.

Cameron, John. 2015. Can Poverty Be Funny? The Serious Use of Humour as a Strategy of Public Engagement for Global Justice. Third World Quarterly, 36(2): 274-290.

Castells, Manuel. 2011. The Rise of the Network Society: The Information Age: Economy, Society, and Culture (Vol. 1). John Wiley \& Sons.

Chadwick, Andrew. 2013. The Hybrid Media System: Politics and Power. Oxford University Press.

Center for Information and Research on Civic Learning and Engagement (CIRCLE). 2014. The Youth Vote in 2012. Center for Information \& Research on Civic Learning \& Engagement. http://www.civicyouth.org/wp-content/uploads/2013/05/ CIRCLE_2013FS_outhVoting2012FINAL.pdf

Colletta, Lisa. 2009. Political Satire and Postmodern Irony in the Age of Stephen Colbert and Jon Stewart. The Journal of Popular Culture 42(5): 856-874.

Feldman, Lauren, Anthony Leiserowitz and Edward Maibach. 2011. The Science of Satire: The Daily Show and The Colbert Report as Sources of Public Attention to Science and the

Environment. In The Stewart/Colbert Effect: Essays on the Real Impacts of Fake Nerws, 25-46. McFarland.

File, Thom. 2013. Young-Adult Voting: An Analysis of Presidential Elections, 1964-2012. United States Census Bureau. http://www.census.gov/prod/2014pubs/p20-573.pdf.

Fowler, James H. 2008. The Colbert Bump in Campaign Donations: More Truthful Than Truthy. Political Science E Politics 41(03): 533-539.

Freedman, Leonard. 2008. The Offensive Art: Political Satire and Its Censorship around the World From Beerbohm to Borat. ABC-CLIO.

Fuchs, Christian. 2009. Grounding Critical Communication Studies: An Inquiry Into the Communication Theory of Karl Marx. Journal of Communication Inquiry.

Gitlin, Todd. 1978. Prime Time Ideology: The Hegemonic Process in Television Entertainment. Soc. Probs 26: 251.

Gray, Jonathan, Jeffrey Jones, and Ethan Thompson. 2009. The State of Satire, The Satire of State. In Satire TV: Politics and Comedy in the Post-Network Era, 3-36. NYU Press.

Holbert, R. Lance, Jay Hmielowski, Parul Jain, Julie Lather and Alyssa Morey. 2011. Adding Nuance to the Study of Political Humor Effects: Experimental Research on Juvenalian Satire Versus Horatian Satire. American Behavioral Scientist.

Hollander, Barry A. 2005. Late-night Learning: Do Entertainment Programs Increase Political Campaign Knowledge for Young Viewers? Journal of Broadcasting E Electronic Media 49(4): 402-415.

Jenkins, Henry. 2009. Confronting the Challenges of Participatory Culture: Media Education for the 21st Century. MIT Press.

2013. Textual Poachers: Television Fans and Participatory Culture. Routledge. 
Kahne, Joseph and Cathy Cohen. 2012. Political Pioneers or Bed Texters? Huffington Post, 3 March. http://www.huffingtonpost.com/joseph-kahne/youth-activismtechnology_b_1646157.html

Kann, Mark E., Jeff Berry, Connor Grant and Phil Zager. 2007. The Internet and Youth Political Participation. First Monday, 12(8).

Kissell, Rick. 2014. Latenight Ratings: NBC's Fallon, Meyers Easy Winners for Q3; ABC's Kimmel, 'Nightline' Up. Variety, 25 September.

Knight, Charles. 2004. The Literature of Satire. Cambridge University Press.

LaMarre, Heather L., Michael A. Beam, Kristen D. Landreville. 2009. The Irony of Satire Political Ideology and the Motivation to See What You Want to See in The Colbert Report. The International Journal of Press/Politics 14(2): 212-231.

McClennen, Sophia. 2011. America According to Colbert: Satire as Public Pedagogy. New York: Palgrave Macmillan.

McClennen, Sophia and Remy Maisel. 2014. Is Satire Saving our Nation? Mockery and American Politics. New York: Palgrave MacMillan.

Moody, Reginald F. 2012.TV Advertising: Lessons for the Public Relations Professional. Public Relations Journal 6(3): 1-39.

Morozov, Evgeny. 2009. The Brave New World of Slacktivism. Foreign Policy 19(05).

Morris, Jonathan S. 2009. The Daily Show With Jon Stewart and Audience Attitude Change During the 2004 Party Conventions. Political Behavior 31(1): 79-102.

Pew Research: Demographics and Political Views of News Audiences.

2012, September 27. http://www.people-press.org/2012/09/27/

section-4-demographics-and-political-views-of-news-audiences/

Rahimi, Babak. 2015. Satirical Cultures of Media Publics in Iran. International Communication Gazette 77(3): 267-281.

Sander, Charles. 1971. The Scope of Satire. Glenview, IL: Scott, Foresman, \& Company.

Schriffin, Deborah. 1996. Narrative as Self-Portrait: Sociolinguistic Constructions of Identity. Language in Society 25: 167-203.

Sklar, Rachel. 2006. Stephen Colbert's Web Dominance: How “The Colbert Report” Is Fast Becoming The Leader In Web-TV Integration. Huffington Post. 22 August. http://www.huffingtonpost.com/eat-the-press/2006/08/22/stephen-colberts-webdom_e_27670.html

Sloam, James. 2014. New Voice, Less Equal The Civic and Political Engagement of Young People in the United States and Europe. Comparative Political Studies 47(5): 663-688.

Spigel, Lynn. 1989. The Domestic Economy of Television Viewing in Postwar America. Critical Studies in Media Communication 6(4): 337-354.

1992. Make Room for TV: Television and the Family Ideal in Postwar America. University of Chicago Press.

Stoker, Gerry. 2006. Why Politics Matters. Making Democracy Work. Palgrave Macmillan.

Strauss, Neill. 2009. Stephen Colbert on Deconstructing the Colbert Nation. Rolling Stone, 22, September. 
Van Heertrum, Richard. 2011. Irony and the News: Speaking Through Cool to American Youth. In The Stewart/Colbert Effect: Essays on the Real Impacts of Fake News, 117-135. Jefferson, NC:McFarland.

Young, Danna Goldthwaite. 2004. Daily Show Viewers Knowledgeable About Presidential Campaign, National Annenberg Election Survey Shows. Philadelphia, PA: Annenberg Public Policy Center. 2006. Late-Night Comedy and the Salience of the Candidates' Caricatured Traits in the 2000 Election. Mass Communication E Society, 9(3): 339-366.

Zuckerman, Ethan. 2014. New Media, New Civics?. Policy E̊ Internet, 6(2): 151-168. 